\title{
Banking Nature? The Spectacular Financialisation of Environmental Conservation
}

\author{
Sian Sullivan \\ Department of Geography, Environment and Development Studies, Birkbeck, \\ University of London, London, UK; \\ s.sullivan@bbk.ac.uk
}

\begin{abstract}
In this paper I emphasise the financialisation of environmental conservation as 1 . the turning of financiers to conservation parameters as a new frontier for investment, and 2. the rewriting of conservation practice and nonhuman worlds in terms of banking and financial categories. I introduce financialisation as a broadly controlling impetus with relevance for environmental conservation. I then note ways in which a spectacular investment frontier in conservation is being opened. I highlight the draw of assertions of lucrative gains, combined with notions of geographical substitutability, in creating tradable indicators of environmental health and harm. I disaggregate financialisation strategies into four categories-nature finance, nature work, nature banking and nature derivatives-and assess their implications. The concluding section embraces Marx and Foucault as complementary thinkers in understanding the transforming intensifications of late capitalism in environmental conservation, and diagnosing their associated effects and costs.
\end{abstract}

Keywords: financialisation, environmental conservation, frontier, primitive accumulation, environmentality, Marx, Foucault

\section{Introduction: Nature's Growing Financial "Value"}

Economic growth and the natural environment are mutually compatible. Sustainable economic growth relies on services provided by the natural environment, often referred to as "ecosystem services" ... [P] rotected natural areas can yield returns many times higher than the costs of their protection. There are multi-million pound opportunities available from greener goods and services, and from markets that protect nature's services. Too many of the benefits we derive from nature are not properly valued. The value of natural capital is not fully captured in the prices consumers pay, in the operations of our markets or in the accounts of government or business (DEFRA 2011:4).

A recent special issue of Antipode on capitalism and conservation, introduced and edited by Daniel Brockington and Rosaleen Duffy (2010), traces how a capitalist "conservationist mode of production" is emerging through consolidated alliances between businesses and organisations funding, facilitating and implementing environmental conservation. With others (eg Adams 2010; Chapin 2004; C MacDonald 2008; K I MacDonald 2010a), they emphasise sustained efforts by conservation organisations, particularly the international environmental nongovernmental organisations (NGOs) of Conservation International, the World Wide Fund for Nature, The Nature Conservancy, the Wildlife Conservation Society, and the African Wildlife Foundation, to recruit big business to a conservation cause 
aligned with neoliberal hegemony. As encapsulated in the quote above from the UK government's current White Paper on the environment, this is supported by systemic embrace of "green growth" as a new frontier for capital expansion, and of markets as the realm through which environmental damage can best be mediated, mitigated and governed (Bayon and Jenkins 2010; Carroll, Fox and Bayon 2008).

Brockington and Duffy (2010:480) assert additionally, however, that "[c]onservation has hardly been involved in the production of value through financialisation", and particularly that conservation organisations have not significantly financialised existing revenue streams from in situ biodiversity conservation. ${ }^{1}$ By contrast, I show how business and finance sectors, in collaboration with conservation organisations, conservation biologists and environmental economists, are engaging in an intensified financialisation of discourses and endeavours associated with environmental conservation and sustainability. As a consequence, environmental arenas are being incorporated into forms of economic expansion associated with financialisation more generally. This tendency permits capital accumulation to be generated through the movement of interest-bearing capital into new areas of social and economic (re)production, even as other areas of production are stagnating (Bellamy Foster and McChesney 2009; Fine 2010).

Diverse commentators agree that key interconnected aspects of this process include deregulation of lending (ie money creation) practices; intensification of money creation through computer-assisted parcelling out and exchanges of debt, prevalent since the 1980s through the "securitisation" and privatisation of mortgage lending (particularly in the USA and the UK); and the repeated bailing out with public sector resources of associated irresponsible lending and investment practices of a finance elite (eg N Ferguson 2009; McNally 2011; G Sullivan 2011). I contend that this "increasing financialisation of everyday life throughout the globe" (Nealon 2008:6) now extends into discourses of environmental conservation and sustainability, combined in part with the financialisation of risk associated with environmental and atmospheric change (Cooper 2010; Lohman 2012; Randalls 2010). As Jason Moore (2010:390) observes, "the penetration of finance into everyday life, and above all into the reproduction of extra-human nature" is a key feature of contemporary capitalism.

My paper traces some ways in which nonhuman ${ }^{2}$ natures and nature dynamics are being financialised through monetisation and marketisation, transformed into yet another means whereby "speculative capital becomes wagered on a future or supposed or projected worth" (Nealon 2008:62). Given the volatility and inequities associated with financialisation more generally (McNally 2011; Strange 1998), it seems pertinent to reflect on the socio-ecological implications of current entanglements of environmental conservation parameters with the financial sphere, as well as to demystify and "de-fetishise" these seemingly complex developments (cf Christophers 2009).

I emphasise how this process of financialisation operates through two entwined phenomena:

1. the turning of banks and financiers to environmental conservation parameters as a new frontier for speculative investment and the creation of additional "value"accumulating financial instruments; 
2. the revisioning and rewriting (cf Szersynski 2010) of conservation practice and understandings of nonhuman natures in terms of banking and financial concepts, enabling conserved "nature" to be entrained with new circuits of monetised exchange and financial instruments.

These movements are taking place in the context of two paradoxes. First, while recent financial crisis might signal that finance markets have reached some sort of expansionary limit (linked in part with possible limits to available borrowers and associated limits to debt-based money creation), bailouts with public money suggest instead that finance has been substantially reinforced, in both resources and the power to command legitimising strategies by national governments (Bellamy Foster and McChesney 2009). Second, while apparent environmental crisis might be interpreted as signalling a developmental crisis of capitalism (J O'Connor 1988), it is instead becoming an accumulation frontier for finance capital through a wholesale reconceptualisation of conserved nature in monetary and tradable terms. This is not only "selling nature to save it" as Kathleen McAfee (1999) incisively put it. It also is the putative saving of nature to trade it.

The "economic profit or political utility" derived from these techniques illuminates how such paradoxical and problematic circumstances are becoming a normalised world-making project (Nealon 2008:58 after Foucault 2003:33). The financialisation of environmental conservation is further rationalising human and nonhuman natures to conform to an economic system that privileges price over other values, and profit-oriented market exchanges over the distributive and sustainable logics of other economic systems (cf Büscher et al in press; Graeber 2001). In doing so it is aligning conservation with holders of expertise and resources in financial realms. By assuming people to be individual utility maximisers and private property to be the norm, it is critically transforming biological, linguistic, cultural and epistemological diversity globally (S Sullivan 2009). Notwithstanding the hybrid possibilities opened by neoliberal market and financial incursions into new socio-ecological spaces (cf J Ferguson 2010; Larner 2000), these reorganisations pose severe challenges for equity in the distribution of wealth and resources (cf Sassen 2010), and for the sustenance and resistances of other ecological knowledges, value practices and "biocultural diversities" (Berkes 1999; Ingold 2000).

My paper attempts to delineate and theorise some of these phenomena via a survey of indicative tendencies and a theoretical exploration of their productively controlling implications. First, I draw attention to mechanisms through which environmental crisis and conservation are being created as a spectacular new frontier for capital investment. I then briefly examine key dimensions of the emerging financialisation of environmental conservation, underscoring four aspects: nature finance, nature work, nature banking, and nature derivatives. My concluding section theorises these interwoven phenomena.

\section{Creating the Spectacular Frontier of Financialised Environmental Conservation}

For finance to "operationalise" the accumulation opportunities of environmental crisis and conservation, products and commodities connecting these domains need 
to be created so as to open new spheres for investment, trade and speculation. As Martin O'Connor (1994:126,133) writes, nature needs to be "capitalised" and "capital ecologised" in new ways. Or to paraphrase Morgan Robertson (2006:368), capital needs to create new natures that it can see, requiring that the earth-in-crisis is rethought and reworded such that it is brought further into alignment conceptually, semiotically, and materially with capital.

Anna Tsing (2005:57) observes additionally that "the self-conscious making of a spectacle is a necessary aid to gathering investment funds" and is "a regular feature of the search for finance capital", requiring combinations of dramatic performance and conjuring tricks in the creation of new trading possibilities. In her words, "the more spectacular the conjuring, the more possible an investment frenzy" (2005:57). Recent events starkly reveal how speculators summon potential for excessive returns, thereby creating commodity bubbles attractive to investors (Soros 2003). While based on multiple layers of product abstraction, such bubbles can have profound social and material effects. As such, it is worth paying attention to how finance capital in collaboration with conservation agendas is creating a new investment frontier in environmental conservation. Here I identify several mutually reinforcing mechanisms of its construction.

First, are repetitive utterances of the spectacular financial returns deemed possible through trade in newly priced environmental conservation commodities. Ever since ecological economist Robert Costanza and colleagues (1997) famously estimated the annual "value" globally of "ecosystem services" and "natural capital" to be \$16-54 trillion, affirmations of nature's dollar value have proliferated. Costanza et al sought to draw attention to ways that exclusion of environmental factors as externalities in conventional economic analyses misrepresented the cost of environmental impacts of development activities. This has been rapidly transformed into an optimistic embrace of the financial returns that might accrue if this "value" of environmental externalities could be priced and traded (for indicative examples, see Bayon 2008:127-128, 131; Bekessy and Wintle 2008:510; Caldecott and Dickie 2011; Conservatives 2010; Madsen, Carroll and Moore Brands 2010:7-8, 16; and the websites www.advancedconservation.org and www.ecosystemmarketplace.org).

Intense work has followed to create and stake claims to newly priced environmental conservation commodities by inventing an expanding product range and associated trading possibilities, based on new abstractions of nonhuman natures and the consequent opening of new niches for investment. Leading this are innovations in the trade of variously derived carbon products marketed as a conserving force in climate management associated with industrial carbon emissions (Lohman 2012). This conceptually enables carbon production as one thing (eg industrial emissions) in one location, to be "offset" against its storage in another, qualitatively different thing (eg tropical forests) in another location (see case studies in Böhm and Dabhi 2009). Such innovations conjure the earth as a carbon matrix in which all production and activity can be reduced to the concentration and profitable exchange of the chemical element carbon (S Sullivan 2010). The possibility of using market exchanges to offset environmental damage in one location through investment in some measure of environmental conservation or restoration in another 
location is an emerging feature of global environmental management and a key mechanism in growing the frontier of environmental financialisation (discussed further below).

Conceptualisation of aspects of the earth's productivity as a frontier of new and profitable substitutabilities engenders understandings of the "global environment" as a sort of abstract global ledger that can be essentialised into newly conceived exchangeable parts. ${ }^{3}$ Technology, particularly the connectivity and networking possibilities of new information and communication technologies (ICTs) and the internet, is playing a critical role in facilitating these innovations and structuring outcomes (Jackson 2009). ICTs permit rapidity and ease of financialised transactions between buyers and sellers, at the same time as shaping the sorts of "products" that can be marketed and traded via electronic exchanges. They are providing online environments for the existence and "scaling up" of nature trading, as evidenced by a proliferation of online trading platforms and exchanges focused on environmental transactions. These include those servicing trade in carbon products, such as the London-based European Climate Exchange (http://www.ecx.eu), the Chicago Climate Exchange (http://www.chicagoclimatex.com) and the Chicago Climate Futures Exchange (http://www.ccfe.com—whose opening page identifies the site as "the leading U.S. Environnmental Derivatives Exchange"). Similar online platforms are emerging to facilitate trade in other environmental conservation products. See, for example, http://www.speciesbanking.com (discussed further in Pawliczek and S Sullivan 2011), and Mission Market's "Earth Exchange", described as "the first online platform facilitating transactions for multiple environmental credits and conservation finance mechanisms". ${ }^{4}$

The frontier of environmental conservation is made further visible through dramatic, technologically mediated and circulated performances. Environmental conservation thus is marketed through media representations of environmental crisis, of the nature treasures that require conservation, and of the conservation activities of key performers in the field, the presentation and circulation of which is enhanced further at spectacularly orchestrated conservation events (cf Brockington 2009; Igoe 2010; Igoe, Neves and Brockington 2010; K I MacDonald 2010b; Smith, Verissimo and MacMillan 2010). What is notable is that such media performances, combined with proliferating mass media products and productions, promote an environmental and conservation spectacle that markets the necessity of investment in environmental conservation, whilst acting to engender particular human-withnature relationships that are balanced in favour of financialised accumulation. Largescale international conservation-oriented events, such as the 4-yearly International Union for the Conservation of Nature (IUCN) World Conservation Congress and the biannual Wildscreen natural history film festival in the UK, thus are orchestrated as spectacles where corporate-conservation and media networks, as well as financialised understandings of nature and conservation interventions, are produced and reinforced (Brockington 2009; K I MacDonald 2010b).

As with any investment frontier such exuberance enables the penetration of finance capital into an expanding array of environmental conservation niches. The process, as I have hinted, involves a discursive framing of nature using financial terms that reorganise conserved nature into concepts that can be productively 
aligned with finance. An exploration of this combined financing and financialised rewriting (Szersynski 2010) of conserved nature comprises the focus of the following section.

\section{Banking Nature: Writing Nature as Money}

The saturation of environmental conservation discourse and practice with financialised terms and concepts is organised here into four interconnected and heuristically relevant domains: nature finance, nature work, nature banking and nature derivatives.

\section{Nature Finance}

The incorporation of environmental conservation and governance for sustainability into the financial sphere is occurring in various ways. They include the emergence of new investment funds specialising in environmental conservation products, the development of environmental indexes to guide and enhance investment products including corporate and government bonds, and the uptake of environmental conservation parameters in the financialising of assets by conventional banks. Together these represent optimism both for investment returns from opportunities in environmental conservation and sustainability, and for the roles that finance itself might play in engendering positive environmental outcomes (Global Canopy Foundation 2010; Kiernan 2009).

First, then, is a growing presence of new investment funds offering products and services that leverage discourses of environmental conservation and sustainability. As "a specialized investment firm focused on discovering and monetizing unrealized or unrecognized environmental assets ... a 'merchant bank' for the world of environmental markets", 5 EKO Asset Management Partners exemplifies this movement. EKO's investors hail from the hyper-elite world of haute finance 6 and aim to "stimulate the development of environmental markets" by aligning "smart capital with people, projects, and companies that are poised to profit from emerging markets for ecosystem services". ${ }^{7}$ Investments are oriented towards "land with undeveloped or unrecognised environmental assets with a view to developing these assets and profiting from their sale in emerging environmental markets". ${ }^{8}$ These statements, echoed elsewhere, ${ }^{9}$ articulate clearly an investment impetus to capitalise on newly created assets in emergent markets for environmental conservation commodities.

Accompanying such investment tendencies is an expansion of environmental indexes designed to guide and enhance investment strategies. The fund managers of Inflection Point Capital Management (IPCM), described as "the world's first multistrategy asset management boutique offering exclusively sustainability-enhanced investment products across a broad range of asset classes", ${ }^{10}$ thus identify "recent market meltdown as a multi-trillion dollar "advertorial" for sustainability-enhanced approaches". ${ }^{11}$ In its wake they aim to increase the "sustainability alpha premium"12 of company profile by incorporating proxy measures of "sustainability performance" into investment practices, based on the proprietary index database developed by associates, Innovest Strategic Value Advisors. 
IPCM is headed by Matthew Kiernan, author of Investing in a Sustainable World: Why Green is the New Color of Money on Wall Street (2009), former President of the World Business Council of Sustainable Development (WBCSD), and regular speaker at the annual Davos World Economic Forum. Innovest is Kiernan's previous company, through which he worked for JPMorgan to create carbon-index-linked corporate bonds that financialise corporate risk associated with climate change (JPMorgan 2007:2). Extensions of this instrument are now being proposed to enable index-linked carbon bonds to also be issued by governments, such that "interest payments [from government to investors] are linked to the actual greenhouse gas emissions of the issuing country against published targets" (London Accord 2009). This would permit investors to hedge against the risk of a government not meeting its carbon commitments, by enabling investors to receive "an excess return if the issuing country's emissions are above the government's published target" and vice versa (London Accord 2009; also Onstwedder and Mainelli 2010). In effect, private sector "green financiers" would control governments on their environmental policies via incentives built into the environmental-index-linked bond structure. The rationale is simple: the issuing government will have added incentive to ensure that national environmental (eg carbon emissions) targets are met because this will enable them to pay lower interest rates on bonds issued to investors. Investors in turn would provide governments with cheaper debt as long as governments meet their targets. This would effectively shift responsibility for global environmental outcomes into the incentivising control of investment finance. Such index-linked bonds seem a counter-intuitive choice for environmental governance in that they entangle environmental management strategies with the unpredictable play of competing profitable domains of speculative investment and hedging activity. It is by no means clear that these would necessarily lead to environmentally (or socially) desirable outcomes. ${ }^{13}$

Conventional banks also are turning their attention towards the financialisation of environmental "assets". The Forest Carbon Partnership Facility of the World Bank, in a recent report entitled Banking on Nature's Assets, thus supports forestrich countries of the global south to enter the global offsetting trade in carbon as a means of generating finance (Ranganathan, Irwin and Procopé Repinski 2009), while the European Investment Bank is collaborating with the University of Stirling's Management School to "design markets for ecosystem service delivery" (or "eco-delivery" as they call it). ${ }^{14}$ Multilateral development banks, themselves increasingly making private sector investments that involve financial intermediaries and private equity funds (Bretton Woods Project 2010), are also being encouraged to "partner countries to sustain their natural capital" by integrating monetised "ecosystem services" in all bank "strategic direction-setting, investment, and advisory services" (Ranganathan, Irwin and Procopé Repinski 2009:5). As such, large bank lenders appear to be financialising their own investment practices (through investing in private sector financial intermediaries), at the same time as encouraging monetisation of national environmental parameters as additional means of creating and mobilising financial assets.

These examples reveal how financialisation is aligning nature with financial spheres. The conceptualisation and writing of nature as a worker and as a bank 
of capital are two discursive tactics through which this is enabled, and which permit the further abstraction of nature into categories amenable to derivative financialised products. I now turn to these.

\section{Nature Work}

The construction of nature as a "service provider" is a significant conceptual move enabling financial investment in measures of, and markets for, nature conservation. Conservation biologists have been using the language of ecosystem services since the 1970s (Bohrmann 1976; Ehrlich 1982). The 2005 publication of the influential United Nations Millennium Ecosystem Assessment (MEA), which highlights humangenerated change of the biosphere, overwhelmingly uses this term to denote the relationship of nonhuman nature to humans (MEA 2005). More recently, the Deputy Head of the Species Programme of the IUCN has stated that "[i]t's time to recognize that nature is the largest company on Earth working for the benefit of 100 percent of humankind-and it's doing it for free" (IUCN 2009).

Such language fabricates nature as a service-providing entity. Of course, any ensuing payments for its services do not return to "nature", but to those who are able to annex them. What becomes significant then are questions regarding what nature work is able to become "billable" (cf Alvehus and Spicer in press) and of who, via enforceable property or ownership rights, can either capture payments for this billable work right away, or profit by speculations on its future value.

The growing discourse on payments for ecosystem services (PES) attempts to resolve these questions. The idea is that those wanting and/or requiring an ecosystem "service" should pay landowners and/or inhabitants for activities that sustain the service, thus fostering conservation outcomes. The ensuing flows and "cascades" of services and payments (Haines-Young and Potschin 2010) can be seen most clearly in the case of downstream water users paying upstream users to maintain water flow and/or quality (Perrot-Maître 2006). Given both the location of valued ecosystems in the "global South", accompanied by need for their services in the industrialised "global North", payments from North to South for service maintenance by the South for the North increasingly are proposed as a means of producing multiple win scenarios. As such they are deemed to align environmental conservation with economic growth (through market expansion) and, in "developing country" contexts, with both poverty reduction and local empowerment (cf UNEP/IUCN 2007). This vision has instigated a systematic and competitive "ecoinformatics" to measure, assess, standardise and disaggregate nature into new "goods and service categories", combined with measures of their health and/or degradation as well as the assigning or market "discovery" of monetary prices for these measures (Kosoy and Corbera 2010; Ruffo and Kareiva 2009). Mapping, measuring and monetisation techniques are thus deployed to produce comprehensive ecosystem services catalogues, applicable from local to global scales (for examples of current and massive public-private ecosystem services identification and valuation initiatives, see Aries Consortium 2009:1; Conservation International 2009:6; Villa et al 2009; the websites http://www.naturalcapitalproject.org/ and http://www.teebweb.org/; and those listed in Herbert et al 2010:33). 
Intrinsic to this endeavour are a range of rapid ecological assessment and economic valuation techniques. The latter rely heavily on contingent valuation or estimates of "willingness to pay", the validity of which has received intense criticism within economics (eg Spash 2008). Ecosystem service valuation projected from unit values (dollar estimates of economic value on a per-unit basis) derived from particular use and non-use values measured at specific sites, are also often computed via the practice of "benefit transfer". This parallels the conceptual device noted above of the substitutability or correspondence between different locations, by permitting the transfer of "economic value estimates from one location to a similar site in another location" - an assumption and practice that again can produce a number of transfer errors (Plummer 2009:39).

These economistic simplifications of socio-ecological complexities capitalise landscapes such that they can be brought into variously financialised exchanges in new ways. In the process, inhabitants of service-producing landscapes also are radically reframed as service maintainers for consumers elsewhere in the emerging global ledger of financialised environmental services. The structuring implications and opportunities for those dwelling in landscapes newly priced for their ecosystem service functions can be profound. This is illustrated by proposals that communities in low-income nations might mortgage the environmental "values" now associated with local landscapes as collateral for affordable financial services provided by international investors in exchange for the conservation of mortgaged environments (Donlan 2009; Mandel et al 2009). In these proposals ecosystem services are to be used as collateral for loans so that people of the "South" can, through indebtedness, be incorporated further into the global monetary economy. Questions arise of who then possesses or has governing powers over the collateral (particularly in the case of default), and of how the pricing of local ecologies intersects with other socially embedded environmental values.

\section{Nature Banking}

Accompanying this creation of nature as billable service provider is a conceptualisation of the health and degradation status of nature's services as akin to a bank account of "natural capital", 15 with implications for the who and how of nature management. Thus, in 1996, Maurice Strong, Secretary General at the 1972 UN Conference on the Human Environment in Stockholm and the 1992 Earth Summit in Rio, and first Executive Director of the UNEP, stated that global environmental sustainability could only be achieved by "running 'Earth Incorporated' with a depreciation, amortization and maintenance account" (Strong 1996). This statement appears in full on the website of EKO Asset Management, the "merchant bank" for environmental markets described above. ${ }^{16} \mathrm{It}$ is also reflected in the UN/EU project on The Economics of Ecosystems and Biodiversity (TEEB), led by a career banker from Deutsche Bank: the recent launch of the TEEB "Bank of Natural Capital" website (http://bankofnaturalcapital.com) represents nature's stocks and flows in a standard online current bank account format.

The entraining of nature concepts with those of banking again affirms "nature's benefits as wealth-creating assets" (Ranganathan, Irwin and Procopé 
Repinski 2009:5) and supports the emergence of "nature banks", managed by nature bankers, as key management structures in environmental governance for conservation (Carroll, Fox and Bayon 2008). Through the monetisation and marketisation of ecosystem services, combined with formalised property rights, landowners (private or collective) thus can become nature entrepreneurs by capitalising on the new nature prices attaching to the increasingly billable nature service work accruing to owned land areas. These "banked" and priced ecosystem services can then be traded via emerging environmental markets designed to facilitate the offsetting of development-related ecosystem transformations against payments for newly valued measures of nature health in nature banks elsewhere (see http://www.speciesbanking.com for a global database of biodiversity and wetlands offsetting initiatives). Ecologically, these sanction habitat loss through development transformations by decoupling the distinctiveness of nonhuman natures from the geographical locales in which they occur. Financially, they create future possibilities for financial accumulation through the bundling together of different environmental products that, as they are distinguished and capitalised, can begin to be banked, offset and traded in combination with each other (Bekessy and Wintle 2008:510).

Private investment is promoted as a key source of funds to support the creation of nature banks and ensuing mitigation banking markets. This is justified in part by a discourse of the growing urgency for private sector finance to fund environmental conservation (Caldecott and Dickie 2011; Global Canopy Foundation 2010), a point surely connected with current over-stretching of public sector resources by bailouts of the financial sector. In combination, the process expands the realm of exchange value at the same time as promising to enhance the asset portfolios of investors through shifting control of environmental conservation into the domain of financial capital. It also opens space for the creation of increasingly abstract commodities such as "nature derivatives".

\section{Nature Derivatives}

I have noted above the proliferation of increasingly derived carbon products as a constitutive aspect of the expanding frontier of conservation markets. The possibility of similarly derived environmental-financial products, or "nature derivatives", in other environmental domains seems likely to augment this frontier.

Indicative here are proposals in a recent paper in Frontiers in Ecology and the Environment for the creation of "biodiversity derivatives" (Mandel, Donlan and Armstrong 2010). Derivatives are financial instruments that promise payments derived from bets on the future value of something else, known as the "underlying" (Stulz 2005:20). Derivative contracts permit businesses to "hedge against the occurrence of unpredictable adverse events" (Cooper 2010:177). As such, they are associated with the construction of risk (including the risk of adverse environmental change) as a tradable commodity (Gudeman 2010:7), whilst also permitting speculative returns based on bets on the chances of the derivatives contract itself (Cooper 2010:177). For biodiversity derivatives, the suggestion is that markets be used to reduce the costs of conservation by applying derivatives to the risk of species extinction. The proposal is that "governments issue modified derivatives contracts 
to sell species' extinction risk to market investors and stakeholders", to provide incentives that take "advantage of the market to reduce costs in conservation" (Mandel, Donlan and Armstrong 2010:44). This, it is argued, will align the interests of conservationists, governments and landowners, by making species presence more valuable to landowners than modifying habitat through development. Contracts would be priced on current interest rates and the probability of a payout or default due to species decline below an agreed threshold. If triggered through species decline, the principal paid by investors would be made available for remediation and recovery of the species in advance of being placed on an endangered species list. ${ }^{17}$ Biodiversity derivatives based on risk of species extinction would be akin to insurance derivatives "issued with modifications to allow responsible action to decrease the likelihood of the insured event" (ie extinction of a species) so as to encourage "social change that is incentivized through market forces" (Mandel, Donlan and Armstrong 2010:45-46).

This transferring of derivatives logic to the domain of species survival (or other aspects of nature decline) seems strange. Futures exchanges might help stabilise prices for storable commodities by balancing sellers' hopes for rising prices with buyers' desire for the opposite. But it seems perverse to transform the value of species survival into a price whose rise or fall is entangled with bets on their susceptibility to irreversible loss, underscored by a calculus whereby species value rises with rarity, or greater risk of extinction. Susan Strange (1998:17) notes that gambling on prices creates "heightened volatility". Is this what is wanted for species presence? Mandel, Donlan and Armstrong (2010:45-46) argue, however, that by issuing a derivative whose value is based on species decline, and "[i]f the trading of species derivatives were responsibly permitted", then "those who do not currently incorporate a conservation ethic into their economic decisions would stand to profit from a change in behaviour towards environmental stewardship". This, of course, is a classic neoliberal suggestion: to design, invest in and legislate for market-based incentives to manipulate behaviours by appealing to the economic self-interest of those with secure land tenure.

Proposals such as this act to enhance the ways that environmental change, itself indelibly and inequitably associated with human activity, can become "a speculative opportunity like any other in a market hungry for critical events" (Cooper 2010:175). In effect, they seek to rationalise nature dynamics, and human contributions to these, to fit the dynamics of financial markets, permitting the assigning of tradable prices to the new unstorable fictitious commodities of essentially unknowable environmental futures (Cooper 2010:176 after Mandelbrot 2004). So while the production of nature work and nature banking described above is rendering nature into a new "mass of standardized, qualitatively indifferent exchange values" (Cooper 2010:180), financialisation here is extending possibilities for nature's speculative release into the realm of circulating money in its new universal form of derivatives. This derivative realm "challenge[s] the idea that the circulation of money must be anchored in some fundamental, underlying value" (Cooper 2010:178), while again binding nature's dynamics and associated wealth-making possibilities to the influence of financial investment in other commodities. This innovative conceptual alignment of nature change with derivative finance products 
acts to materially enhance the fortunes of investors and their associated impacts, whilst shifting control of environmental governance to the speculative expectations governing financial futures markets. It is capturing a nature of unpredictable flows and dynamism such that these are able to circulate as money, the power and material effects of which are concealed through the abstract and seemingly virtual milieu of its movement.

In this section I have traced the transformation of conserved nature into discrete "billable hours" and bankable assets, whose release onto markets in variously derived forms is facilitating an expanding and spectacular investment frontier. The novel and frequently opaque ecology of associated terms and concepts on which this frontier feeds constitutes a systematic new wave of semiotic and material enclosures of "the global environment". It is creating an innovative product range of complex, virtual and mobile nature products to produce a tradable "derivative nature" (Büscher 2010), which, although increasingly abstract, nonetheless has significant material effects. As Brand and Görg (2008:568) write for the international governance of genetic plant resources, such innovations and intensifications are based on "a new constitution of the object itself and of new processes of its practical appropriation". As such, they warrant vigilant and critical attention.

In the concluding section I theorise these emerging phenomena and their world-making effects. I am guided here by Nealon (2008:22), who argues for the complementarities between Marxian and Foucaultian diagnoses of historically intensifying economic practices and the political significance of "how and what they produce".

\section{Conclusion: Contemporary Primitive Eco-accumulation, and the Environmentality of "Earth Incorporated"}

In this paper I have documented the creation of a frontier of interlocking new commodities, markets, investments and speculative practices associated with, and justified by, financialised discourses of environmental crisis, conservation and sustainability. Capitalism conventionally grows through investment and innovation in commodity production accompanied by necessary expansions of populations of producer-consumers. With financialisation, the "virtual production of money directly from money" (Nealon 2008:63) is intensified, while remaining nonetheless connected with underlying movements of the prices of diverse product entities and speculative bets on these. I have traced various ways in which conserved nonhuman nature is being conceptually rearranged so as to align with such financegenerating practices. I turn now to a theorisation of these processes, informed by the complementary analyses of capital's intensifying power effects in the writings of Karl Marx and Michel Foucault.

The Marxian concept of "primitive accumulation", tellingly reframed by David Harvey (2003) as "accumulation by dispossession", remains of diagnostic utility in understanding both raison d'être and momentum of this expanding green capitalist frontier. Primitive accumulation was the term deployed by Marx (1974 [1867]) 
to denote the initial creation and capture of surplus necessary for all subsequent capitalist relations of production and exchange. For Marx, the two critical enclosures are of land as property and human activity as labour. These required the historical rift of each from the other, or the disembedding of people from land-entwined social relations, as Karl Polanyi put it (2001 [1944]). Other scholars highlight additional forms of primitive accumulations as integral to the capitalist strategy of bending nature in situ, as well as human life and bodies, to the commodity form (Federici 2004; Perelman 2001).

All such accumulations of productive forces that are not a priori manufactured for sale require dramatic, albeit subsequently naturalised, conceptual transformations. The conversion of land into private property, which underscores the current wave of financialised ecology-commodity creation, thus requires the rejection of prior values, access or use rights so that land itself becomes capital that can be owned for most intents and purposes absolutely. Its abstracted monetary price, linked with associated resources and amenities, is then able to rise and fall in relation to other commodities, and its deterritorialised exchange is able to occur at a distance with money as symbolic medium and measure of 'value'. In combination, it is the transformation of land and human activity from subject to object that permits their reification as marketable commodities (de Angelis 2001:7). This is a process that disregards and makes strange the myriad other practices of relationship, value and ethical requirements enacted by people in relation to nonhuman natures (Basso 1983; Berkes 1999; Ingold 2000; Viveiros de Castro 2004).

Marx states that "[a]s soon as capitalist production is on its own legs, it not only maintains this separation [of labour from the means of capitalist production], but reproduces it on a continually extending scale" (Marx 1974 [1867):668). Massimo de Angelis (2001) thus refers to the ontological, as opposed to historical, condition of capitalist production. Many other authors have stressed this ongoing nature of "primitive accumulation", from Rosa Luxemburg writing in 1913, to David Harvey writing in 2010. As such, recent analyses frame the process as "continuous" (de Angelis 2001), "permanent" (Bonefeld 2001; Harvey 1975) and "contemporary" (Glassman 2006).

The current proliferation of new nature values and tradable commodities for environmental conservation can be understood as a similar and spectacularly productive wave of primitive accumulation. They are structuring ostensibly untransformed and variously restored nonhuman natures into reified, exchangeable and financialised commodity forms in previously unthought ways (Kosoy and Corbera 2010), at the same time as creating additional ways of bringing diverse peoples into the global market as producer-consumers of these new commodity forms. Primitive "eco-accumulation" in this reading is the engine driving this series of expansionary and overlapping intensifications in the commodification of life itself, to more fully saturate and subsume "the eco-socius" (cf Nealon 2008:84).

As Nealon (2008:21) affirms, Foucault extends Marx's brilliance in tracing capitalism's productive mechanisms and power effects. The arguments presented here come into clearer focus when also considered through the Foucaultian frames of the two most recent and overlapping layers of power's transformation, namely disciplinary power and biopolitical control. In service to the engine of continuous 
primitive accumulation capital power is rewriting the eco-socius through its technical disciplining into a new series of monetised entities through ecosystem service science and environmental economics; and the marketised and financialised release of these ecosystem entities into the totalising and biopolitical control of the smooth flows of capital associated with globalised finance.

In Discipline and Punish Foucault (1991 [1975]) emphasised that new regimes of governance are structured and bolstered by new social sciences, which recursively and productively reinforce new disciplining techniques of management and administration. At the time of the rise of the bourgeois class and the Age of Reason in Europe, he makes much of the accompanying presence of a novel spirit that partitions, makes distinctions, classifies, codifies and calculates (Foucault 1991 [1975]:137-138; also Federici 2004:ch 4). He is talking here about the body, and of the new social sciences that helped to construct, subject, manage and accumulate the body as a utility-maximising "body-machine", as well as to rationalise and administer bodies as populations. In the contemporary era of primitive eco-accumulation that accompanies neoliberal environmental governance, we are witnessing an intensification of these tendencies into productively scarce socio-ecological domains. Just as the new sciences of demography, nutrition, etc made possible the administrations of the modern era through the application of accounting to social relations, ecosystem service science today is effecting the application of accounting to socio-environmental relations, also in service to particular administrative regimes.

Nonhuman nature thus is being made docile through a conceptual transformation that seeks to catch it "in a [new] system of subjection", whereby its productive characteristics can be further "calculated, organized, technically thought" and "invested with power relations" (Foucault 1991 [1975]:24-26). Like the human body, and the body-politic of populations, conserved nature as service provider and store of capital is "entering a machinery of power that explores it, breaks it down and rearranges it" to productively bend and release its immanent forces towards economic utility (1991 [1975]:138, 170). Through "ecoinformatics", ecological and economics data are connected and entrained so as to create "value" at various ecosystem scales, through a process that mirrors the "accumulation by molecularisation" (Nally 2011) that is being made possible through capital investment in bioinformatics at the scale of molecular biology. These infiltrations of capital at both large and small scales of nature are "amplifying power's effects within a wider economic field of calculation" (Nealon 2008:27) by consolidating claims to unforeseen domains and inventions (Prudham 2007) of life. The "micro-physics of power" operating in the capillaries and institutional apparatuses of ecosystem service science thus is strategically reshaping socio-environment relations such that they are those of "Earth Incorporated". The reign of money's sign over all aspects of nonhuman nature has come to occupy centre stage in ongoing intensifications of financialised eco-control.

In later work, Foucault (2008 [1979]) elaborates this intensification as biopolitical governmentality effected by the "truth regime" of the market under neoliberalism. Extending this to environmental arenas thus engenders an "environmentality" (Fletcher 2010; Luke 1995) whereby all environmental phenomena are rendered 
intelligible and governable through insertion into financialised logics. In the environmentality of Earth Incorporated, the art of government in relation to "environmental conservation" will be practised, by necessity, through the subordination of all environmental concerns to the market's logic, such that all environmental indices become framed, banked, traded, circulated, and speculated on as forms of capital.

Current rationalisations and monetisations of nature in terms of the disaggregated, commodified and banked services "it" provides, thus constitute a new mechanisation of nature management to satisfy discourses of efficiency (Federici 2004:70) in the realm of environmental conservation, whilst maintaining accumulation as "the engine which powers growth under the capitalist [conservationist] mode of production" (Harvey 1975:9). As such, they can be regarded as variously productive power effects, which permit the repositioning and territorialisation of vast regions of the world as sites for capitalised global ecosystem services conservation and supply (Sassen 2010:30). By further secularising nonhuman nature and human-with-nature relationships they constitute a massive rendering mute (Curry 2008) of both nonhuman nature and of the nature knowledges and value practices associated with non-capitalist ways of living. The displacement effects of this restructuring range from so-called "green land grabs" for conservation (Fairhead, Leach and Scoones forthcoming) to the more subtle erasure of knowledges and values that are outside the logic of this financialising impetus (Berkes 1999; Ingold 2000; Sullivan 2009, 2010).

It seems pertinent to remember Polanyi's (2001 [1944]:187) description of the transformation of land into the commodity form as "perhaps the weirdest of all the undertakings of our ancestors". Currently we are in the midst of an equally revolutionary shift in discourses and practices regarding a global geography of nonhuman natures and associated cultural diversities. While these build on extant understandings of land as commodity and of private property, they extend these in radical ways to release new nature "values" that can be traded, invested in and speculated on via conceptual and capitalised conversion into the commodity form. To paraphrase Marx (1974 [1867]:698), once again a "new social soul" is popping into the body of nature, with associated privileges and exclusions. I hope in this paper to have clarified some aspects of this new "soul", so as to contribute to the consolidation of critical and resistant responses.

\section{Acknowledgements}

This work has been through several iterations and benefited from numerous commentators, to whom I express my gratitude. Thanks in particular to Vinay Gidwani, Dan Brockington, Bram Büscher, Rosaleen Duffy, Mike Hannis, Jim Igoe, Molly Scott Cato, and an anonymous reviewer for suggestions regarding this submission to Antipode. Any remaining errors of interpretation are mine alone.

\section{Endnotes}

1 Emails to author from Daniel Brockington and Rosaleen Duffy, 25 May 2011.

2 I use the term "nonhuman" nature(s) when referring to organisms, entities and contexts other than the modern common sense understanding of the biological species of Homo sapiens. I note, however, that for many cultures that personify the "nonhuman" and lean 
towards assumption of one humanity and many different embodied perspectives, this is itself problematic and even nonsensical. In the ontological domain of shamanic "perspectivism", for example, there are no "nonhumans" (Viveiros de Castro 2004).

3 Thank you to Jim Igoe for illuminating discussion on this point.

${ }^{4}$ http://mmearth.com (last accessed 20 June 2011).

5 http://ekoamp.com (last accessed 4 March 2011).

${ }^{6}$ http://ekoamp.com/who/ (last accessed 4 March 2011).

7 http://ekoamp.com/approach/ (last accessed 4 March 2011).

8 http://ekoamp.com/approach/ (last accessed 4 March 2011).

9 See, for example, the Terra Bella fund of Terra Global Capital described as "a private investment fund specialising in assets from environmental markets", including "emerging ecosystem markets" and "under-valued derivative instruments on environmental assets" (http://terraglobalcapital.com/Funds.htm, last accessed 1 August 2011). For more on this impetus it is worth listening to the recent "webinar" organised by Mission Markets" ${ }^{\mathrm{TM}}$ (described as "the world's first comprehensive marketplace created for buyers, sellers and other stakeholders within the impact and sustainability sectors"; http://missionmarkets.com/resources/webinars/biodiversity, last accessed 21 June 2011).

10 http://www.inflectionpointcm.com/ (last accessed 4 March 2011).

11 http://www.inflectionpointcm.com/timing.html (last accessed 4 March 2011).

12 http://www.inflectionpointcm.com/investhesis.html (last accessed 4 March 2011).

13 Thank you to my colleague Martin Frost for talking me through the history and workings of government-issued bonds, to Leland Lehrman for including me in a recent email discussion regarding green-indexing, and to Geoff Chesshire for subsequent discussion. Ben Caldecott (2011) of the environmental investment firm Climate Change Capital (http://www.climatechangecapital.com) outlines a range of additional "green bonds".

14 http://www.eco-delivery.stir.ac.uk/ (last accessed 1 August 2011). Nb. US\$3-5 billion of green bonds were issued by multilateral institutions in 2010, according to Cranford et al (2011:10).

15 As an anthropological aside I note that Nurit Bird-David (1992) suggests that banks constitute an appropriate metaphor for understanding the conceptualisation of the provisioning role(s) of nonhuman nature held by small-scale "hunter-gatherer" societies. Although some aspects of the metaphor are relevant, problems arise when considering the tendency of monetary banks to massively leverage, ie stretch, the resources at their disposal. Whilst this might "grow" the resources seemingly available, current circumstances emphasise that it can also create the sort of unsustainable crisis scenarios that "hunter-gatherers" tend to work to minimise (eg S Sullivan 1999). Thank you to Keith Hart for drawing my attention to Bird-David's arguments.

16 http://www.ekoamp.com/who/ (last accessed 21 June 2011).

17 I am grateful to the financial expertise of Colin Cafferty in illuminating some aspects of biodiversity derivatives.

\section{References}

Adams W A (2010) Conservation plc. Oryx 44:482-484

Alvehus J and Spicer A (in press) Financialization as a strategy of workplace control in professional service firms. Critical Perspectives on Accounting

Aries Consortium (2009) The ARIES Project: Artificial Intelligence for Ecosystem Services. http://esd.uvm.edu/uploads/media/ARIES.pdf (last accessed 7 December 2009)

Basso K H (1983) "Stalking with stories": Names, places, and moral narratives among the western Apache. In E Bruner (ed) Text, Play and Story: The Construction and Reconstruction of Sect and Society (pp 19-53). Long Grove, IL: Waveland Press

Bayon R (2008) Banking on biodiversity. In Worldwatch Institute (ed) Innovations for a Sustainable Economy (pp 123-239). Washington: Worldwatch Institute

Bayon R and Jenkins M (2010) The business of biodiversity. Nature 466:184-185

Bekessy S A and Wintle B A (2008) Using carbon investment to grow the biodiversity bank. Conservation and Policy 22(3):510-513 
Bellamy Foster J and McChesney R (2009) Monopoly-finance capital and the paradox of accumulation. Monthly Review October, http://www.monthlyreview.org/091001fostermcchesney.php (last accessed 23 August 2010)

Berkes F (1999) Sacred Ecology. London: Routledge

Bird-David N (1992) Beyond "The original affluent society": A culturalist reformulation. Current Anthropology 33(1):25-47

Böhm S and Dabhi S (eds) (2009) Upsetting the Offset: The Political Economy of Carbon Markets. London: Mayfly Books

Bohrmann FH (1976) An inseparable linkage: Conservation of natural ecosystems and the conservation of fossil energy. BioScience 26:754-760

Bonefeld W (2001) The permanence of primitive accumulation: Commodity fetishism and social constitution. The Commoner 2

Brand U and Görg C (2008) Post-Fordist governance of nature: The internationalization of the state and the case of genetic resources-a Neo-Poulantzian perspective. Review of International Political Economy 15(4):567-589

Bretton Woods Project (2010) The private sector turn: Private equity, financial intermediaries and what they mean for development. http://www.brettonwoodsproject.org/ art.shtml?x=566623 (last accessed 23 September 2010)

Brockington D (2009) Celebrity and the Environment: Fame, Wealth and Power in Conservation. London: Zed Books

Brockington D and Duffy R (2010) Capitalism and conservation: The production and reproduction of biodiversity conservation. Antipode 42(3):469-484

Büscher B (2010) Derivative nature: Interrogating the value of conservation in "boundless Southern Africa". Third World Quarterly 31(2):259-276

Büscher B, Sullivan S, Neves K, Igoe J and Brockington D (in press) Towards a synthesized critique of neoliberal conservation. Capitalism, Nature, Socialism.

Caldecott B (2011) What exactly are green bonds? The Guardian 11 January. http:// www.guardian.co.uk/environment/cif-green/2011/jan/11/what-are-green-bonds (last accessed 21 June 2011)

Caldecott B and Dickie I (2011) Habitat Banking. London: Climate Change Capital and EFTEC

Carroll N, Fox J and Bayon R (eds) (2008) Conservation and Biodiversity Banking: A Guide to Setting Up and Running Biodiversity Credit Trading Systems. London: Earthscan

Chapin M (2004) A challenge to conservationists. World Watch Magazine 17(6):16-31

Christophers B (2009) Complexity, finance and progress in human geography. Progress in Human Geography 33(6):807-824

Conservation International (2009) Nature Provides: Ecosystem Services and Their Benefits to Humankind. http://www.conservation.org/Documents/Cl_EcosystemServices_Brochure.pdf (last accessed 21 June 2011)

Conservatives (2010) Open source planning. Policy Green Paper 14. http://www. conservatives.com/ /media/Files/Green\%20Papers/planning-green-paper.ashx (last accessed 21 June 2011)

Cooper M (2010) Turbulent worlds: Financial markets and environmental crisis. Theory, Culture \& Society 27(2-3):167-190

Costanza R, d'Arge R, de Groot S, Farber M, Grasso B, Hannon K, Limburg S, Naeem R, O'Neill J, Paruelo R, Raskin R, Sutton P and van den Belt M (1997) The value of the world's ecosystem services and natural capital. Nature 387:253-260

Cranford M, Henderson IR, Mitchell AW, Kidney S and Kanak DP (2011) Unlocking Forest Bonds: A High-Level Workshop on Innovative Finance for Tropical Forests, Workshop Report. WWF Forest and Climate Initiative, Global Canopy Programme and Climate Bonds Initiative

Curry P (2008) Nature post-nature. New Formations 64:51-64

De Angelis M (2001) Marx and primitive accumulation: the continuous character of capital's "enclosures". The Commoner 2

DEFRA (2011) The Natural Choice: Securing the Value of Nature. London: UK Government

Donlan CJ (2009) Why environmentalism needs high finance. http://seedmagazine.com/ content/article/why_envronmentalism_needs_high_finance/ 22 April (last accessed 7 December 2009) 
Ehrlich P R (1982) Human carrying capacity, extinctions and nature reserves. BioScience 32:331-333

Fairhead J, Leach $\mathrm{M}$ and Scoones I (forthcoming) Green grabbing: A new appropriation of nature? Journal of Peasant Studies

Federici S (2004) Caliban and the Witch: Women, the Body and Primitive Accumulation in Medieval Europe. New York: Autonomedia

Ferguson J (2010) The uses of neoliberalism. Antipode 41(s1):166-184

Ferguson N (2009) The Ascent of Money: A Financial History of the World. London: Penguin

Fine B (2010) Locating financialisation. Historical Materialism 18(2):97-116

Fletcher R (2010) Neoliberal environmentality: Towards a poststructural political ecology of the conservation debate. Conservation and Society 8(3):171-181

Foucault M (1991 [1975]) Discipline and Punish: The Birth of the Prison (trans A Sheridan). London: Penguin

Foucault M (2003) "Society Must be Defended": Lectures at the College de France, 1975-1976 (trans D Macey). New York: Picador

Foucault M (2008 [1979]) The Birth of Biopolitics: Lectures at the Collège de France 1978-1979 (trans G Burchell). Basingstoke: Palgrave Macmillan

Glassman J (2006) Primitive accumulation, accumulation by dispossession, accumulation by "extra-economic" means. Progress in Human Geography 30(5):608-625

Global Canopy Foundation (2010) The Little Biodiversity Finance Book: A Guide to Proactive Investment in Natural Capital (PINC). Oxford: Global Canopy Programme

Graeber D (2001) Towards an Anthropological Theory of Value: The False Coin of our Own Dreams. Basingstoke: Palgrave Macmillan

Gudeman S (2010) Creative destruction: Efficiency, equity or collapse? Anthropology Today 26(1):3-7

Haines-Young R and Potschin M (2010) The links between biodiversity, ecosystem services and human well-being. In D Raffaelli and C Frid (eds) Ecosystem Ecology: A New Synthesis (pp 110-139). Cambridge: Cambridge University Press

Harvey D (1975) The geography of capitalist accumulation: a reconstruction of the Marxian theory. Antipode 7(2):9-21

Harvey D (2003) The New Imperialism. Oxford: Oxford University Press

Harvey D (2010) The Enigma of Capital and the Crises of Capitalism. London: Profile Books

Herbert T, Vonada R, Jenkins M, Bayon R and Leyva J M F (2010) Environmental Funds and Payments for Ecosystems Services: RedLAC Capacity Building Project for Environmental Funds. Rio de Janeiro: RedLAC

Igoe J (2010) The spectacle of nature and the global economy of appearances: Anthropological engagements with the spectacular mediations of transnational conservation. Critique of Anthropology 30(4):375-397

Igoe J, Neves K and Brockington D (2010) A spectacular eco-tour around the historic bloc: Theorizing the convergence of biodiversity conservation and capitalist expansion. Antipode 42(3):486-512

Ingold T (2000) The Perception of the Environment: Essays in Livelihood, Dwelling and Skill. London: Routledge

IUCN (2009) Wildlife Crisis Worse Than Economic Crisis. http://www.iucn.org/about/work/ programmes/species/?3460/Wildlife-crisis-worse-than-economic-crisis-IUCN (last accessed 10 August 2009)

Jackson A (2009) ICT and the new global investment paradigm: Challenges to crossborder trade and investment. World Customs Journal 3(1):55-61

JPMorgan (2007) Introducing the JENI-Carbon Beta Index. http://www.eco-life.fr/ references/JPMorgan\%20-\%20Introducing\%20the\%20JENI-Carbon\%20Beta\%20Index. pdf?PHPSESSID=eab265c4b5d1ead7211e0654e9f580d9 (last accessed 4 March 2011)

Kiernan M J (2009) Investing in a Sustainable World: Why Green is the New Color of Money on Wall Street. New York: Amacom

Kosoy N and Corbera E (2010) Payments for ecosystem services as commodity fetishism. Ecological Economics 69(6):1228-1236 
Larner W (2000) Theorising neoliberalism: Policy, ideology, governmentality. Studies in Political Economy 63:5-26

Lohman L (2012) Financialization, commodification and carbon: The contradictions of neoliberal climate policy. Socialist Register 48:85-107

London Accord (2009) Index linked carbon bonds, http://www.london-accord.co.uk/ wiki/index.php/Index-Linked_Carbon_Bonds (last accessed 4 May 2010)

Luke T W (1995) On environmentality: Geo-power and eco-knowledge in the discourse of contemporary environmentalism. Cultural Critique 31(II):57-81

Luxemburg R (2003 [1913]) The Accumulation of Capital. London: Routledge

MacDonald C (2008) Green Incorporated: An Environmental Insider Reveals How a Good Cause Has Gone Bad. Guilford: The Lyons Press

MacDonald K I (2010a) The devil is in the (bio)diversity: Private sector "engagement" and the restructuring of biodiversity conservation. Antipode 42(3):513-550

MacDonald K I (2010b) Business, biodiversity and new "fields" of conservation: The World Conservation Congress and the renegotiation of organizational order. Conservation and Society 8(4):256-275

Madsen B, Carroll N and Moore Brands K (2010) State of Biodiversity Markets Report: Offset and Compensation Programs Worldwide. http://www.ecosystemmarketplace. com/documents/acrobat/sbdmr.pdf (last accessed 24 October 2011)

Mandel J, Donlan J and Armstrong J (2010) A derivative approach to endangered species conservation. Frontiers in Ecology and the Environment 8(1):44-49

Mandel J T, Donlan C J, Wilcox C, Cudney-Bueno R, Pascoe D and Tulchin D (2009) Debt investment as a tool for value transfer in biodiversity conservation. Conservation Letters 2(5):233-239

Mandelbrot B (2004) The (Mis)Behaviour of Markets: A Fractal View of Risk, Ruin and Reward. London: Profile Books

Marx K (1974 [1867]) Capital, Vol I (trans S Moore and E Aveling). London: Lawrence and Wishart

McAfee K (1999) Selling nature to save it? Biodiversity and green developmentalism. Environment and Planning D: Society and Space 17(2):133-154

McNally D (2011) Global Slump: The Economics and Politics of Crisis and Resistance. Pontypool: The Merlin Press

MEA (2005) Millennium Ecosystem Assessment: Ecosystems and Human Well-being. Washington DC: Island Press

Moore J (2010) The end of the road? Agricultural revolutions in the capitalist world-ecology, 1450-2010. Journal of Agrarian Change 10(3):389-413

Nally D (2011) The biopolitics of food provisioning. Transactions of the Institute of British Geographers 36:37-53

Nealon J T (2008) Foucault Beyond Foucault: Power and its Intensifications since 1984. Stanford: Stanford University Press

O'Connor J (1988) Capitalism, nature, socialism: A theoretical introduction. Capitalism, Nature, Socialism 1:11-38

O'Connor M (1994) On the misadventures of capitalist nature. In M O'Connor (ed) Is Capitalism Sustainable? Political Economy and the Politics of Ecology (pp 125-151). London: Guilford Press

Onstwedder J-P and Mainelli M (2010) Living up to their promises (index-linked carbon bonds). Environmental Finance Feb: 17

Pawliczek J and Sullivan S (2011) Conservation and concealment in SpeciesBanking.com, US: An analysis of neoliberal performance in the species offsetting service industry. Environmental Conservation 38(4):435-444

Perelman M (2001) The secret history of primitive accumulation and classical political economy. The Commoner 2

Perrot-Maître D (2006) The Vittel Payments for Ecosystem Services: A "Perfect" PES Case? London: International Institute for Environment and Development (IIED)

Plummer ML (2009) Accessing benefit transfer for the valuation of ecosystem services. Frontiers in Ecology and the Environment 7(1):38-45 
Polanyi K (2001 [1944]) The Great Transformation: the Political and Economic Origins of Our Time. Boston: Beacon Press

Prudham S (2007) The fictions of autonomous intervention: Accumulation by dispossesssion, commodification and life patents in Canada. Antipode 39(3):406-429

Randalls S (2010) Weather profits: Weather derivatives and the commercialization of meteorology. Social Studies of Science 40:705-730

Ranganathan J, Irwin F and Procopé Repinski C (2009) Banking on Nature's Assets: How Multilateral Development Banks Can Strengthen Development by Using Ecosystem Services. Washington: World Resources Institute

Robertson M M (2006) The nature that capital can see: science, state, and market in the commodification of ecosystem services. Environment and Planning D: Society and Space 24:367-387

Ruffo S and Kareiva P M (2009) Using science to assign value to nature. Frontiers in Ecology and the Environment 7:3

Sassen S (2010) A savage sorting of winners and losers: contemporary versions of primitive accumulation. Globalizations 7(1):23-50

Smith R J, Verissimo D and MacMillan D C (2010) Marketing and conservation: How to lose friends and influence people. In N Leader-Williams, W M Adams and R J Smith (eds) Trade-offs in Conservation: Deciding What to Save (pp 215-232). Oxford: Blackwell

Soros G (2003) The Alchemy of Finance. London: Wiley

Spash C (2008) Ecosystems services valuation. Socio-economics and the Environment in Discussion, CSIRO Working Paper Series. http://csiro.au/files/files/pjpj.pdf (last accessed 21 February 2009)

Strange S (1998) What theory? The theory in Mad Money. CSGR Working Paper. http://www2.warwick.ac.uk/fac/soc/csgr/research/workingpapers/1998/wp1898.pdf (last accessed 23 August 2009)

Strong M (1996) "A new 'rich-poor' war". Lecture to the Korea Institute for International Economic Policy, Seoul, Korea, 22 October. http://www.mauricestrong.net/ 2009032079/speeches2/speeches2/korea-economic-policy.html (last accessed 30 November 2009)

Stulz R M (2005) Demystifying financial derivatives. Milken Institute Review Third Quarter: 20-31

Sullivan G (2011) The Making of a One-Handed Economist. Brighton: Book Guild Publishing

Sullivan S (1999) Folk and formal, local and national: Damara cultural knowledge and community-based conservation in southern Kunene, Namibia. Cimbebasia 15:1-28

Sullivan S (2009) Green capitalism and the cultural poverty of constructing nature as serviceprovider. Radical Anthropology 3:18-27

Sullivan S (2010) "Ecosystem service commodities" - a new imperial ecology? Implications for animist immanent ecologies, with Deleuze and Guattari. New Formations 69:111-128

Szersynski B (2010) Reading and writing the weather: Climate technics and the moment of responsibility. Theory, Culture \& Society 27(2-3):9-30

Tsing A L (2005) Friction: An Ethnography of Global Connection. Princeton, NJ: Princeton University Press

UNEP/IUCN (2007) Developing international payments for ecosystem services: Towards a greener world economy, http://www.unep.ch/etb/areas/ pdf/IPES_IUCNbrochure.pdf(last accessed 23 September 2008)

Villa F, Ceroni M, Bagstad K, Johnson G and Krivov S (2009) ARIES (Artificial Intelligence for Ecosystem Services): A new tool for ecosystem services assessment, planning, and valuation. BioEcon, http://www.ucl.ac.uk/bioecon/11th_2009/Villa.pdf (last accessed 7 December 2009)

Viveiros de Castro E (2004) Exchanging perspectives: The transformation of objects into subjects in Amerindian ontologies. Common Knowledge 10(3):463-484 